\title{
Short-Term, Combined Fasting and Exercise Improves Body Composition in Healthy Males
}

\author{
Giuseppe delli Paoli \\ Università degli Studi della Campania \\ "Luigi Vanvitelli" and European \\ Consortium for Lifestyle, Exercise, \\ Adaptation, and Nutrition (EULEAN)
}

\section{Antonia Giacco}

Università degli Studi del Sannio and European

Consortium for Lifestyle, Exercise, Adaptation, and Nutrition (EULEAN)

\author{
Stefano M. Pagnotta \\ Università degli Studi del Sannio
}

\author{
Denise van de Laarschot and \\ Edith C.H. Friesema \\ Erasmus University Medical Center \\ and European \\ Consortium for Lifestyle, Exercise, \\ Adaptation, and Nutrition (EULEAN)

\section{Rosalba Senese} \\ Università degli Studi della Campania \\ "Luigi Vanvitelli" and European \\ Consortium for Lifestyle, Exercise, \\ Adaptation, and Nutrition (EULEAN) \\ Linda Broer \\ Erasmus University Medical Center
}

\author{
Remco Verkaik \\ European Nutraceutical Services and \\ European \\ Consortium for Lifestyle, Exercise, \\ Adaptation, and Nutrition (EULEAN)
}

Pascal P. Arp and P. Mila Jhamai Erasmus University Medical Center

André G. Uitterlinden

Erasmus University Medical Center and European

Consortium for Lifestyle, Exercise, Adaptation, and Nutrition (EULEAN)

\author{
M. Carola Zillikens \\ Erasmus University Medical Center \\ and European \\ Consortium for Lifestyle, Exercise, \\ Adaptation, and Nutrition (EULEAN)
}

\begin{abstract}
Pieter de Lange
Università degli Studi della Campania "Luigi Vanvitelli" and European Consortium for Lifestyle, Exercise, Adaptation, and Nutrition (EULEAN)
\end{abstract}

Fasting enhances the beneficial metabolic outcomes of exercise; however, it is unknown whether body composition is favorably modified on the short term. A baseline-follow-up study was carried out to assess the effect of an established protocol involving short-term combined exercise with fasting on body composition. One hundred seven recreationally exercising males underwent a 10-day intervention across 15 fitness centers in the Netherlands involving a 3-day gradual decrease of food intake, a 3-day period with extremely low caloric intake, and a gradual 4-day increase to initial caloric intake, with daily 30-min submaximal cycling. Using dual-energy X-ray absorptiometry analysis, all subjects substantially lost total body mass $(-3.9 \pm 1.9 \mathrm{~kg} ; p<.001)$ and fat mass $(-3.3 \pm 1.3 \mathrm{~kg} ; p<.001)$. Average lean mass was lost $(-0.6 \pm 1.5 \mathrm{~kg} ; p<.001)$, but lean mass as a percentage of total body mass was not reduced. The authors observed a loss of $-3.9 \pm 1.9 \%$ android fat over total fat mass $(p<.001)$, a loss of $-2.2 \pm 1.9 \%$

\footnotetext{
(C) 2020 The Authors. Published by Human Kinetics, Inc. This is an Open Access article distributed under the terms of the Creative Commons Attribution 4.0 International License, CC BY 4.0, which permits unrestricted noncommercial and commercial use, distribution, and reproduction in any medium, provided the original work is properly cited, the new use includes a link to the license, and any changes are indicated. See http://creativecommons.org/licenses/by/4.0. This license does not cover any third-party material that may appear with permission in the article.

delli Paoli, van de Laarschot, Zillikens, and de Lange contributed equally to the work. delli Paoli, Senese, Lanni, and de Lange are with the Dipartimento di Scienze e Tecnologie Ambientali, Biologiche e Farmaceutiche, Università degli Studi della Campania "Luigi Vanvitelli", Caserta, Italy. van de Laarschot, Arp, Jhamai, Broer, Uitterlinden, and Zillikens are with the Division of Endocrinology, Department of Internal Medicine, Erasmus University Medical Center, Rotterdam, The Netherlands. Friesema is with the Division of Pharmacology, Vascular and Metabolic Diseases, Erasmus University Medical Center, Rotterdam, The Netherlands. Verkaik is with European Nutraceutical Services (E.N.S.) B.V., Rotterdam, The Netherlands. Giacco and Pagnotta are with Dipartimento di Scienze e Tecnologie, Università degli Studi del Sannio, Benevento, Italy. delli Paoli, van de Laarschot, Friesema, Verkaik, Giacco, Senese, Uitterlinden, Lanni, Zillikens, and de Lange are with the European Consortium for Lifestyle, Exercise, Adaptation, and Nutrition (EULEAN), Erasmus MC Rotterdam, The Netherlands, University of Campania, Caserta, Italy, University of Sannio, Benevento, Italy, and German Sports University, Cologne, Germany. de Lange (pieter.delange@ unicampania.it) is corresponding author.
} 
gynoid over total fat mass $(p<.001)$, and reduced android/gynoid ratios $(-0.05 \pm 0.1 ; p<.001)$. Analyzing 15 preselected singlenucleotide polymorphisms in 13 metabolism-related genes revealed trending associations for thyroid state-related singlenucleotide polymorphisms rs225014 (deiodinase 2) and rs35767 (insulin-like growth factor1), and rs1053049 (PPARD). In conclusion, a short period of combined fasting and exercise leads to a substantial loss of body and fat mass without a loss of lean mass as a percentage of total mass.

Keywords: DXA scan, male subjects, SNPs

It is currently estimated that $40 \%$ of the European population is affected by overweight and obesity (Agha \& Agha, 2017). The loss of excessive fat and improved body composition is warranted, and reduced energy intake combined with increased energy expenditure through physical activity are scientifically recognized as possible solutions to this public health challenge (Jaspers et al., 2017). Previously performed studies on the beneficial effect of fasting and endurance exercise (for 12 and 6 weeks, respectively; Bhutani et al., 2013; Van Proeyen et al., 2011) did not include data on body composition. Studies that included body composition either involved caloric restriction alone (2 years; Das et al., 2017) or combined with resistance exercise (4 weeks; Stratton et al., 2020). Both studies reported an efficient loss of fat mass, without a loss of lean mass in the latter. Applying a fasting/exercise protocol in the general population would thus be desirable, preferably with a shorter time span. This led to the idea to develop a 10-day training program termed Sportfasting (Verkaik, 2015), which was introduced to Health and Fitness clubs in The Netherlands, that could be completed by the average, nonathletic person. However, the outcomes of this protocol have not yet been scientifically evaluated.

Fasting-induced metabolic reprogramming involves peroxisome proliferator-activated receptor (PPAR) $\gamma$ coactivator- $1 \alpha$ (PGC- $1 \alpha$; de Lange et al., 2006) and PPAR $\delta$ (de Lange et al., 2006, 2008, Wijngaarden et al., 2014), reminiscent to that of endurance exercise (Anton et al., 2017; de Lange et al., 2007; Jaspers et al., 2017). One key physiological factor determining fat mass and body composition is the thyroid state (Samuels et al., 2017). Indeed, with skeletal muscle being a major target (Senese et al., 2014), thyroid hormones have been proposed to be considered exercise mimetics (Jaspers et al., 2017). In relation to this, data obtained in exercised rodents have demonstrated an enhanced activity of muscle deiodinase 2 (DIO2), converting $3,5,3^{\prime}, 5^{\prime}$-tetraiodo-L-thyronine (T4) into the metabolically active 3,5,3'-triiodo-l-thyroinine (T3), associated with increased expression of PGC-1 $\alpha$ (Bocco et al., 2016). We have recently shown that mild exercise in rats submitted to $66 \mathrm{hr}$ (23/4 day) of food withdrawal (a simplified protocol reminiscent to that used in the current study) boosts the expression of genes involved in lipid metabolism, including PGC-1 $\alpha$, DIO2, and insulin-like growth factor 1 (IGF1) receptor (Giacco et al., 2020), suggesting increased IGF1 signaling (Douyon \& Schteingart, 2002).

The aim of this study was to develop a rapid, noninvasive approach to assess the outcome of the short-term Sportfasting protocol. We verified whether the intervention led to a considerable weight loss and whether the protocol would also lead to beneficial changes in body composition. It should be noted that various aspects of human physiology are typically complex genetic traits, meaning that interindividual variation is determined by numerous genetic variants, including those in the above described factors (Walter et al., 2012). Thus, we also wanted to explore whether the success of the intervention could be related to genetic predisposition. Therefore, we set out to investigate the effect of the Sportfasting protocol on body mass and, using dualenergy X-ray absorptiometry (DXA) on circumferences, fat mass and lean mass. In addition, using genomic DNA isolated from the participants' saliva samples, we explored the effect of 15 preselected single- nucleotide polymorphisms (SNPs) in 13 candidate genes involved in muscle metabolism and body composition. Several of these genes are associated with the thyroid state, including angiotensinogen-converting enzyme (Vasiliadis et al., 2014) and peroxisome proliferator-activated receptor (PPAR) $\gamma$ (Ohkubo et al., 2019), as well as the aforementioned PGC-1 $\alpha$ (Bocco et al., 2016), DIO2 (Bocco et al., 2016; Canani et al., 2005), and IGF1 (Douyon \& Schteingart, 2002).

\section{Methods}

\section{Participants}

Between January 2015 and November 2017, 107 randomly selected male White subjects, ranging in age from 21 to 61 years, were asked to engage in a baseline-follow-up study after they decided to voluntarily follow an established Sportfasting protocol, as provided in Health and Fitness clubs across 15 centers in The Netherlands. We selected males for this study to exclude the variable hormonal influences in women on the outcomes (Muñoz et al., 2020). Male participants were recruited in fitness centers and personal training studios, and their inclusion was evaluated based on a short questionnaire based on which their health and fitness status was assessed (see Addendum). Prior to the intervention, a questionnaire and a 3-day food diary were used to exclude abnormal low caloric intake and vegan or vegetarian or otherwise low-carb diets. Participants with caloric intake below $1,800 \mathrm{kcal}$ were excluded. Participants should be engaged in recreational sports activity, with a minimum average of three times a week. Semiprofessional or professional athletes were excluded from the intervention study. Written informed consent for participation and publication of the related data was obtained from all volunteers, and the study on outcomes was approved by the Medical Ethical Committee from Erasmus MC, Rotterdam, The Netherlands (nWMO2014; see Table 1 for participant characteristics).

\section{Sportfasting Protocol}

The participants were enrolled in the existing 10-day Sportfasting protocol (Verkaik, 2015). Briefly, the protocol consists of three phases. During Phase 1 (Days 1-3), the participants consumed a prescribed diet containing 1,800,1,200, and $800 \mathrm{kcal}$ on Days 1, 2 and 3 , respectively. Water consumption was ad libitum, and the

\section{Table 1 Characteristics of the Participants}

\begin{tabular}{lcccc}
\hline Characteristic & $\boldsymbol{N}$ & Minimum & Maximum & Mean \\
\hline Male sex (100\%) & 107 & & & \\
Ethnicity: White (100\%) & 107 & & & \\
Age (years) & & 21.0 & 61.0 & $41.7 \pm 9.7$ \\
Height (cm) & 165.0 & 200.0 & $183.7 \pm 7.3$ \\
Baseline body mass (kg) & 67.6 & 126.2 & $92.1 \pm 12.3$ \\
Baseline BMI $\left(\mathrm{kg} / \mathrm{m}^{2}\right)$ & 21.2 & 37.6 & $27.3 \pm 3.2$ \\
\hline
\end{tabular}

Note. Values are minimal, maximal, and mean $\pm S D ; n$, number of participants. $\mathrm{BMI}=$ body mass index . 
participants were advised to drink a minimum of $2 \mathrm{~L}$ per day. During Phase 2 (Days 4-6), the participants consumed $189 \mathrm{kcal} /$ day in liquid form $(3 \times 150-\mathrm{ml}$ apple juice [Biologische Appelsap furnished by Albert Heijn BV., Zaandam, The Netherlands]), consisting of (per $100 \mathrm{ml}$ ): 42-kcal metabolizable energy, 0.0-g protein, 11.0-g carbohydrates, $0.0-\mathrm{g}$ fat, $0.2 \mathrm{-g}$ fruit fibers, $0.01-\mathrm{mg} \mathrm{Na}^{+}$]. During Phase 3 (Days 7-10), the participants consumed a prescribed diet containing $800,1,200,1,800$, and 2,200 kcal on Days 7, 8, 9, and 10, respectively. The diets are described in detail in Verkaik, 2015. Throughout the entire period, the participants cycled for $30 \mathrm{~min}$ at $70-75 \%$ of their relative maximum heart rate and used four separate nutritional supplements (A-D) daily. These supplements (described in detail in Verkaik, 2015) were used in order to prevent depletion of essential components (especially essential amino acids, vitamins, and minerals) due to the relative intensity of Phase 2 of the protocol. All supplement components were from Fittergy B.V., Rotterdam, the Netherlands, and the supplements were manufactured by EHF nutrition B.V., Rotterdam, The Netherlands (website: https://www.ehf-group.nl). Compliance with the prescribed supplements was documented with a supplement log by the participants. The participants continued the prescribed diet of 2,200 kcal (Verkaik, 2015) while returning to their daily routine recreational activities until the follow-up DXA measurement. After completing the program, the participants were advised to maintain a daily caloric intake of around $2,200 \mathrm{kcal}(20 \%$ protein, $20 \%$ fat, and $60 \%$ carbohydrates).

\section{Body Mass, Height, and Composition Measurements}

Body mass and height were measured with a digital scale (Tanita DC-360 S, Tanita Corp., Tokyo, Japan) and a wall-mounted measuring tape (Seca206; Seca GMBH, Hamburg, Germany), respectively. Whole-body DXA (Lunar Prodigy, enCORE 2011, General Electric, software 14.10.022, Madison, WI) was used to assess the participants' body composition, including fat and lean mass, and android and gynoid fat. The DXA measurements used for subsequent calculations were carried out in one center in the morning, 2 hr after a standardized 350-kcal breakfast, 1 day before the start, and within 7-10 days after the completion of the protocol. This time period was chosen to avoid misinterpretation due to acute changes in tissue glycogen and hydration resulting from the protocol (Bone et al., 2017).

\section{Genotyping}

Genomic DNA was isolated from saliva samples according to the manufacturer's instructions (Oragene DNA Self Collection Kit; DNA Genotec, Ottawa, ON, Canada). The samples were processed using a PUREGENE DNA purification kit (DNA Genotek's Oragene) and analyzed by the Human Genomics Facility (HuGeF; www.glimdna.org) at Erasmus MC (Rotterdam, The Netherlands). We selected 15 SNPs related to body composition and endurance parameters, of which, seven were also studied by Tsianos et al. (2010) in marathon runner athletes. For all SNPs, Taqman assays were generated and applied according to the manufacturer's specifications (Applied Biosystems, Foster City, CA). Analysis was performed with the ABI Taqman $7900 \mathrm{HT}$, using sequence detection system 2.22 software (Applied Biosystems). Analysis accuracy was confirmed by regenotyping 20 randomly selected samples (5\% of the total sample number) with the same method. All primers and probes are available upon request. The genotype frequencies of the 15 selected SNPs are presented in Table 2, and all were in Hardy Weinberg Equilibrium after adjusting for multiple testing.

\section{Statistical Analyses}

Statistical analysis was performed in R (R Core Team, 2017). The data are presented as mean $\pm S D$. The main experimental question related to the design translated into the following alternative hypothesis: "the participants at follow-up show a decrease in the values measured at baseline," that is, follow-up $<$ baseline. In this context, the follow-up versus baseline values reported in Table 3 were evaluated for statistical significance using a paired $t$ test. Considering the number of participants under study $(n=107)$, according to the central limit theorem, the test-statistic is asymptotically Gaussian. In addition, the baseline, follow-up, and delta values of total body mass $(\mathrm{kg})$, lean mass $(\mathrm{kg})$, and body mass index (BMI, $\mathrm{kg} / \mathrm{m}^{2}$ ) were analyzed by linear regression analysis, which was inconclusive. Per SNP, we evaluated an association with total body mass, total lean mass, and BMI at the baseline and follow-up, as well as with the changes in these parameters between the follow-up and baseline. To assess the association between the phenotype and each SNP, we performed a $t$ test with Welch's correction. Our results are trends that do not persist upon adjustment for multiple testing.

\section{Results}

\section{Cohort Characteristics}

A total of 107 male study participants engaged in the Sportfasting protocol. Age (years): $41.7 \pm 9.7$, height $(\mathrm{cm}): 183.7 \pm 7.3$, baseline body mass $(\mathrm{kg}): 92.1 \pm 12.3$, baseline BMI $\left(\mathrm{kg} / \mathrm{m}^{2}\right): 27.3 \pm 3.2$ (Table 1).

\section{Body Mass Versus Body Composition Changes}

The results of the body composition analyses of the participants are shown in Table 3. The Sportfasting protocol resulted in a loss of $3.9-\mathrm{kg}$ total body mass $(-3.9 \pm 1.9 \mathrm{~kg}, p<.001)$. The decrease in total fat mass was $3.3 \pm 1.3 \mathrm{~kg}, p<.001$. Mean BMI also decreased $(-1.2 \pm 0.6, p<.001)$. There was a decrease in fat mass as a percentage of total body mass $(-2.6 \pm 1.2, p<.001)$. Total fat mass as a percentage of total lean mass decreased by $-4.9 \pm 2.4$ $(p \leq .001)$. In the whole group, total lean mass changed by $-0.6 \pm 1.5 \mathrm{~kg}(p<.001)$, whereas total lean mass as a percentage of total body mass did not change $(2.4 \pm 1.3, p=1.00)$.

\section{The Sportfasting Protocol Reduces the Android/ Gynoid Fat Mass Ratio}

We compared the percentage of android fat over total fat versus gynoid fat over total fat at the baseline and follow-up (Table 3). The loss of android fat $(-3.9 \pm 1.9 \mathrm{~kg}, p<.001)$ was greater than that of gynoid fat $(-2.2 \pm 1.9 \mathrm{~kg}, p<.001)$, with significant but mild differences in the ratio of android over gynoid fat $(-0.05 \pm 0.1$, $p<.001)$. We found no evidence for a difference in response based on the preintervention android/gynoid fat ratio.

\section{Genetic Analyses}

The 15 analyzed SNPs and their related functions inherent to performance, body composition, and insulin sensitivity are presented 
Table 2 Analysis of the Genotype Frequency of 15 SNPs in 106 Men

\begin{tabular}{|c|c|c|c|c|c|c|c|c|c|c|}
\hline GENE & SNPID & & Genotypes, & number (\%) & & Major allele & Minor allele & $N$ & MAF & HWE \\
\hline $\mathrm{ACE}$ & rs1799752 & I: 26 (24.5) & ID: 49 (46.2) & D: $26(24.5)$ & $\begin{array}{l}\text { Undetermined: } \\
5(4.7)\end{array}$ & $\mathrm{D}$ & I & 101 & 0.50 & 0.96 \\
\hline ACTN3 & rs1815739 & CC: 37 (34.9) & CT: 46 (43.4) & TT: 21 (19.8) & $\begin{array}{l}\text { Undetermined: } \\
2(1.9)\end{array}$ & $\mathrm{C}$ & $\mathrm{T}$ & 104 & 0.42 & 0.63 \\
\hline PPARA & rs4253778 & GG: 63 (59.4) & CG: 35 (33.0) & CC: 6 (5.7) & $\begin{array}{l}\text { Undetermined: } \\
2(1.9)\end{array}$ & G & $\mathrm{C}$ & 104 & 0.23 & 0.93 \\
\hline PPARD & $\begin{array}{l}\text { rs6902123 } \\
\text { rs1053049 }\end{array}$ & $\begin{array}{c}\text { TT:91 (85.8) } \\
\text { TT: } 62(58.5)\end{array}$ & $\begin{array}{l}\text { CT: } 12(11.3) \\
\text { CT: } 34(32.1)\end{array}$ & $\begin{array}{ll}\text { CC: } 1 & (0.9) \\
C C: & 8(7.5)\end{array}$ & $\begin{array}{c}\text { Undetermined: } \\
2 \text { (1.9) } \\
\text { Undetermined: } \\
2(1.9)\end{array}$ & $\begin{array}{l}\mathrm{T} \\
\mathrm{T}\end{array}$ & $\begin{array}{l}\mathrm{C} \\
\mathrm{C}\end{array}$ & $\begin{array}{l}104 \\
104\end{array}$ & $\begin{array}{l}0.07 \\
0.24\end{array}$ & $\begin{array}{l}0.71 \\
0.57\end{array}$ \\
\hline PPARG & rs1801282 & CC: 74 (69.8) & CG: 27 (25.5) & GG: 3 (2.8) & $\begin{array}{l}\text { Undetermined: } \\
2(1.9)\end{array}$ & $\mathrm{C}$ & G & 104 & 0.16 & 0.96 \\
\hline PPARGC1A & rs8192678 & CC: 48 (45.3) & CT: 42 (39.6) & TT: 14 (13.2) & $\begin{array}{l}\text { Undetermined: } \\
2(1.9)\end{array}$ & $\mathrm{C}$ & $\mathrm{T}$ & 104 & 0.34 & 0.62 \\
\hline APOE & $\begin{array}{c}\text { rs74412 } \\
\text { rs429358 }\end{array}$ & $\begin{array}{l}\text { other/other: } \\
84 \text { (79.2) }\end{array}$ & $\begin{array}{l}\epsilon 4 \text { /other: } \\
19 \text { (17.9) }\end{array}$ & $\begin{array}{l}\epsilon 4 / € 4: \\
1(0.9)\end{array}$ & $\begin{array}{l}\text { Undetermined: } \\
2(1.9)\end{array}$ & $\epsilon 2, \epsilon 3$ & $€ 4$ & 104 & 0.10 & 1.00 \\
\hline AMPD1 & rs 17602729 & GG: 83 (78.3) & AG: 20 (18.9) & AA: $1(0.9)$ & $\begin{array}{l}\text { Undetermined: } \\
2(1.9)\end{array}$ & G & A & 104 & 0.11 & 0.99 \\
\hline BDKRB2 & rs1799722 & CC: 37 (34.9) & CT: 45 (42.5) & TT: 22 (20.8) & $\begin{array}{l}\text { Undetermined: } \\
2(1.9)\end{array}$ & $\mathrm{C}$ & $\mathrm{T}$ & 104 & 0.254 & 0.238 \\
\hline ADRB2 & rs 1042713 & GG: 42 (39.6) & AG: 45 (42.5) & AA: 17 (16.0) & $\begin{array}{l}\text { Undetermined: } \\
2(1.9)\end{array}$ & G & A & 104 & 0.38 & 0.71 \\
\hline IGF1 & rs35767 & GG: 61 (57.5) & AG: 33 (31.1) & AA: 5 (4.7) & $\begin{array}{c}\text { Undetermined: } \\
7(6.6)\end{array}$ & G & A & 99 & 0.22 & 0.98 \\
\hline MnSOD & rs 4880 & AA: $32(30.2)$ & GA: 48 (45.3) & GG: 24 (22.6) & $\begin{array}{l}\text { Undetermined: } \\
2(1.9)\end{array}$ & A & G & 104 & 0.46 & 0.77 \\
\hline $\mathrm{DIO} 2$ & rs225014 & TT: 46 (43.4) & CT: 37 (34.9) & CC: 21 (19.8) & $\begin{array}{c}\text { Undetermined: } \\
2(1.9)\end{array}$ & $\mathrm{T}$ & $\mathrm{C}$ & 104 & 0.38 & 0.04 \\
\hline
\end{tabular}

Note. For APOE, the two SNPs are linked and define six possible genotypes $(\epsilon 2 / \epsilon 2, \epsilon 2 / \epsilon 3, \epsilon 3 / \epsilon 3 /, \epsilon 3 / \epsilon 4, \epsilon 4 / \epsilon 4$, and $\epsilon 2 / \epsilon 4)$. SNPID = single-nucleotide polymorphism identification number; $N=$ number of subjects; $\mathrm{MAF}=$ minor allele frequency; HWE $=$ Hardy Weinberg Equilibrium. Further abbreviations: see Table 4 .

Table 3 Comparison of Pre- and Postsport Fasting Body-Composition Variables

\begin{tabular}{|c|c|c|c|c|c|c|}
\hline \multirow[b]{2}{*}{ Variable } & \multirow{2}{*}{$\frac{\text { Baseline }}{\text { Mean } \pm S D}$} & \multirow{2}{*}{$\frac{\text { Follow-up }}{\text { Mean } \pm S D}$} & \multicolumn{3}{|c|}{ Change $(\Delta)$} & \multirow[b]{2}{*}{$p$ value } \\
\hline & & & Mean $\Delta S D(S E)$ & Minimum $\Delta$ & Maximum $\Delta$ & \\
\hline Total body mass & $92.1 \pm 12.3$ & $88.2 \pm 11.5$ & $-3.9 \pm 1.9(0.2)$ & -0.1 & -11.4 & $<.001$ \\
\hline Total lean mass & $63.2 \pm 5.8$ & $62.6 \pm 5.7$ & $-0.6 \pm 1.5(0.1)$ & 2.4 & -5.8 & $<.001$ \\
\hline Total fat mass & $25.3 \pm 8.8$ & $22.0 \pm 8.5$ & $-3.3 \pm 1.3(0.1)$ & -0.3 & -6.9 & $<.001$ \\
\hline BMI $\left(\mathrm{kg} / \mathrm{m}^{2}\right)$ & $27.3 \pm 3.2$ & $26.1 \pm 3.0$ & $-1.2 \pm 0.6(0.1)$ & 0.0 & -3.0 & $<.001$ \\
\hline Total fat mass ( $\%$ of total body mass) & $26.8 \pm 6.7$ & $24.3 \pm 7.0$ & $-2.6 \pm 1.2(0.0)$ & 0.3 & -5.7 & $<.001$ \\
\hline Total lean mass ( $\%$ of total body mass) & $69.2 \pm 6.5$ & $71.6 \pm 6.8$ & $2.4 \pm 1.3(0.1)$ & -0.5 & 6.2 & 1.0 \\
\hline Total fat mass ( $\%$ of total lean mass) & $40.0 \pm 13.2$ & $35.1 \pm 13.1$ & $-4.9 \pm 2.4(0.2)$ & 1.0 & -13.0 & $<.001$ \\
\hline Android fat mass ( $\%$ of total fat mass $)^{a}$ & $38.4 \pm 9.1$ & $34.5 \pm 10.0$ & $-3.9 \pm 1.9(0.2)$ & 0.1 & -8.4 & $<.001$ \\
\hline Gynoid fat mass ( $\%$ of total fat mass) & $29.6 \pm 6.5$ & $27.4 \pm 6.8$ & $-2.2 \pm 1.9(0.2)$ & 1.8 & -7.5 & $<.001$ \\
\hline Android/gynoid fat mass ${ }^{\mathrm{a}}$ & $1.3 \pm 0.2$ & $1.25 \pm 0.2$ & $-0.05 \pm 0.1(0.0)$ & -0.3 & 0.4 & $<.001$ \\
\hline
\end{tabular}

Note. Mass values are in kilograms. Values are means $\pm S D(S E)$. Positive $\Delta$ values represent gain and negative $\Delta$ values represent loss. BMI $=$ body mass index.

a missing values $n=1$.

in Table 4. The genotype frequencies of the analyzed SNPs are presented in Table 2. At the baseline, the $\mathrm{C}$ allele variant of rs225014 (DIO2) is associated with 7\% higher body mass (94.62 kg for C-allele carriers vs. $88.27 \mathrm{~kg}$ for noncarriers, $p=$ $.007), 5 \%$ higher lean mass (64.27 $\mathrm{kg}$ for $\mathrm{C}$-allele carriers vs.
$61.55 \mathrm{~kg}$ for noncarriers, $p=.019)$, and 5\% higher BMI (27.82$\mathrm{kg} / \mathrm{m}^{2} \mathrm{C}$-allele carriers vs. $26.44 \mathrm{~kg} / \mathrm{m}^{2}$ for noncarriers, $p=.024$ ). At the follow-up, these trends were maintained: $7 \%$ higher body mass $(90.60 \mathrm{~kg}$ for $\mathrm{C}$-allele carriers vs. $84.58 \mathrm{~kg}$ for noncarriers, $p=.007), 4 \%$ higher lean mass (63.63 kg for C-allele carriers vs. 
Table 4 Analyzed SNPs and Related Functions Inherent to Muscle Metabolism and Function

\begin{tabular}{|c|c|c|c|c|c|c|}
\hline Gene & Name & Major role & SNPID & $\begin{array}{l}\text { Nucleotide } \\
\text { change }\end{array}$ & $\begin{array}{l}\text { Genomic } \\
\text { location/ } \\
\text { amino acid } \\
\text { change }\end{array}$ & $\begin{array}{l}\text { Molecular function of the resulting } \\
\text { alleles in the working muscle }\end{array}$ \\
\hline ACE & $\begin{array}{l}\text { Angiotensin- } \\
\text { converting } \\
\text { enzyme }\end{array}$ & $\begin{array}{l}\text { Conversion of } \\
\text { Angiotensin I into } \\
\text { Angiotensin II }\end{array}$ & rs1799752 & $\begin{array}{l}\text { I/D of Alu } \\
\text { repeat }\end{array}$ & Intron 16 & $\begin{array}{l}\text { D allele is associated with higher ACE } \\
\text { activity, leading to decreased capillary-to- } \\
\text { fiber ratio and thus decreased substrate } \\
\text { delivery to the working muscle (Valdivieso } \\
\text { et al., 2017). }\end{array}$ \\
\hline ACTN3 & $\alpha_{3}$-Actinin & $\begin{array}{l}\text { Skeletal muscle } \\
\text { component }\end{array}$ & rs1815739 & $\begin{array}{l}\mathrm{C}>\mathrm{T} \\
(\mathrm{C} \rightarrow \text { Arg } \\
\mathrm{T} \rightarrow \text { Ter })\end{array}$ & Arg577Ter & $\begin{array}{l}\text { Stop codon leads to absence of } \alpha \text {-actinin- } 3 \text {, } \\
\text { which may increase the damage produced in } \\
\text { the sarcomere during exercise (Del Coso } \\
\text { et al., 2019). }\end{array}$ \\
\hline PPARA & $\operatorname{PPAR} \alpha$ & Lipid metabolism & rs 4253778 & $\mathrm{G}>\mathrm{C}$ & Intron 7 & $\begin{array}{l}\text { GG leads to increased muscle Type I fibers } \\
\text { enhancing oxidative capacity (Eynon et al., } \\
\text { 2010). }\end{array}$ \\
\hline PPARD & PPAR $\delta$ & Lipid metabolism & $\begin{array}{l}\text { rs6902123 } \\
\text { rs1053049 }\end{array}$ & $\begin{array}{l}\mathrm{T}>\mathrm{C} \\
\mathrm{T}>\mathrm{C}\end{array}$ & $\begin{array}{l}\text { Intron } 2 \\
\text { 3'UTR }\end{array}$ & $\begin{array}{l}\text { rs6902123, rs } 1053049 \text { TT: Increased muscle } \\
\text { fat-free mass upon lifestyle intervention } \\
\text { (Thamer et al., 2008). }\end{array}$ \\
\hline PPARG & PPAR $\gamma$ & Lipid metabolism & rs1801282 & $\begin{array}{l}\mathrm{C}>\mathrm{G} \\
(\mathrm{C} \rightarrow \text { Pro, } \\
\mathrm{G} \rightarrow \text { Ala })\end{array}$ & Pro12Ala & $\begin{array}{l}\text { Pro variant leads to decreased muscle insulin } \\
\text { sensitivity and Ala variant leads to increased } \\
\text { muscle oxidative capacity (Petr et al., 2018). }\end{array}$ \\
\hline PPARGC1A & $\begin{array}{l}\operatorname{PPAR} \gamma \\
\text { coactivator-1 } \alpha \\
(\mathrm{PGC}-1 \alpha)\end{array}$ & $\begin{array}{l}\text { Regulation of energy } \\
\text { metabolism }\end{array}$ & rs8192678 & $\begin{array}{l}\mathrm{C}>\mathrm{T} \\
(\mathrm{C} \rightarrow \mathrm{Gly} \\
\mathrm{T} \rightarrow \text { Ser })\end{array}$ & Gly482Ser & $\begin{array}{l}\text { Gly variant leads to increased Type I fibers } \\
\text { and mitochondrial activity (Petr et al., 2018), } \\
\text { and Ser variant leads to decreased PGC-1 } \\
\text { expression (Povel et al., 2010). }\end{array}$ \\
\hline APOE & $\begin{array}{l}\text { Apolipoprotein } \\
\text { E }\end{array}$ & $\begin{array}{l}\text { Interaction and catab- } \\
\text { olism of lipoproteins }\end{array}$ & $\begin{array}{l}\text { rs } 7412 \\
\text { rs429358 }\end{array}$ & $\begin{array}{l}\mathrm{C}>\mathrm{T} \\
\mathrm{C}>\mathrm{T} \\
(\mathrm{C} \rightarrow \text { Arg } \\
\mathrm{T} \rightarrow \mathrm{Cys})\end{array}$ & $\begin{array}{l}\text { Arg176Cys } \\
\text { Arg130Cys }\end{array}$ & $\begin{array}{l}\text { Both rs: Cys variant leads to reduced high- } \\
\text { density lipoprotein cholesterol levels } \\
\text { (Hagberg et al., 1999) and increased muscle } \\
\text { oxidative capacity (Thompson et al., 2004). }\end{array}$ \\
\hline AMPD1 & $\begin{array}{l}\text { AMP deami- } \\
\text { nase-1 }\end{array}$ & $\begin{array}{l}\text { Skeletal muscle } \\
\text { metabolism }\end{array}$ & rs17602729 & $\begin{array}{l}\mathrm{G}>\mathrm{A} \\
(\mathrm{G} \rightarrow \mathrm{Gln} \\
\mathrm{A} \rightarrow \mathrm{Ter})\end{array}$ & Gln45Ter & $\begin{array}{l}\text { Stop codon inhibits repletion of ATP during } \\
\text { exercise-induced muscle contraction (Ronca } \\
\text { \& Raggi, 2018). }\end{array}$ \\
\hline BDKRB2 & $\begin{array}{l}\text { Bradykinin } \mathrm{B}_{2} \\
\text { receptor }\end{array}$ & Bradykinin receptor & rs1799722 & $\mathrm{C}>\mathrm{T}$ & 5'UTR & $\begin{array}{l}\mathrm{T} \text { allele increases blood pressure and heart } \\
\text { rate responses during exercise in men (Notay } \\
\text { et al., 2018). }\end{array}$ \\
\hline ADRB2 & $\begin{array}{l}\beta_{2} \text {-Adrenergic } \\
\text { receptor }\end{array}$ & Adrenergic receptor & rs1042713 & $\begin{array}{l}\mathrm{G}>\mathrm{A} \\
(\mathrm{G} \rightarrow \mathrm{Gly} \\
\mathrm{A} \rightarrow \mathrm{Arg})\end{array}$ & Gly16Arg & $\begin{array}{l}\text { Gly variant is associated with greater muscle } \\
\text { fat-free mass and maximal voluntary iso- } \\
\text { metric strength (Jenkins et al., 2018). }\end{array}$ \\
\hline IGF1 & $\begin{array}{l}\text { Insulin-like } \\
\text { growth factor } 1\end{array}$ & $\begin{array}{l}\text { Regulation of growth } \\
\text { and development }\end{array}$ & rs35767 & $\mathrm{G}>\mathrm{A}$ & $\begin{array}{l}-1,191 \mathrm{bp} \\
\text { upstream of } \\
\text { IGF1 }\end{array}$ & $\begin{array}{l}\text { An (minor) allele associated with higher } \\
\text { circulation of IGF1 leading to increased } \\
\text { muscle mass (Ben-Zaken et al., 2013). }\end{array}$ \\
\hline MnSOD & $\begin{array}{l}\text { Manganese- } \\
\text { dependent } \\
\text { superoxide } \\
\text { dismutase }\end{array}$ & $\begin{array}{l}\text { Inactivation of super- } \\
\text { oxide derived from } \\
\text { mitochondrial oxida- } \\
\text { tive metabolism }\end{array}$ & rs 4880 & $\begin{array}{l}\mathrm{A}>\mathrm{G} \\
(\mathrm{A} \rightarrow \mathrm{Val} \\
\mathrm{G} \rightarrow \text { Ala })\end{array}$ & Val16Ala & $\begin{array}{l}\text { Val variant leads to imbalance of protein } \\
\text { production (McAtee \& Jager, 2010). }\end{array}$ \\
\hline $\mathrm{DIO} 2$ & $\begin{array}{l}\text { Type II io- } \\
\text { dothyronine } \\
\text { deiodinase }\end{array}$ & $\begin{array}{l}\text { Thyroid hormone } \\
\text { conversion }\end{array}$ & rs225014 & $\begin{array}{l}\mathrm{T}>\mathrm{C} \\
(\mathrm{T} \rightarrow \mathrm{Thr} \\
\mathrm{C} \rightarrow \text { Ala })\end{array}$ & Thr92Ala & $\begin{array}{l}\text { Ala variant exhibits a } 10 \% \text { loss of thyroid } \\
\text { hormone conversion activity in vitro (Canani } \\
\text { et al., 2005). }\end{array}$ \\
\hline
\end{tabular}

Note. PPAR = peroxisome proliferator-activated receptor; $\mathrm{SNP}=$ single-nucleotide polymorphism; SNPID = single-nucleotide polymorphism identification number.

$61.17 \mathrm{~kg}$ for noncarriers, $p=.032)$, and $5.5 \%$ higher BMI (26.84$\mathrm{kg} / \mathrm{m}^{2}$ C-allele carriers vs. $25.35 \mathrm{~kg} / \mathrm{m}^{2}$ for noncarriers, $\left.p=.024\right)$. This did not affect the response to the Sportfasting intervention (Figure 1a). The $\mathrm{C}$ allele variant of rs1053049 (PPARD) is also associated with a $5 \%$ higher baseline body mass $(94.66 \mathrm{~kg}$ for $\mathrm{C}$ allele carriers vs. $89.89 \mathrm{~kg}$ for noncarriers, $p=.050)$ and with a $5 \%$ higher follow-up body mass $(90.67 \mathrm{~kg}$ for C-allele carriers vs. $86.09 \mathrm{~kg}$ for noncarriers, $p=.049)$, again not affecting the response to the Sportfasting intervention (Figure 1b). Furthermore, we observed an association between the A allele of rs 35767
(IGF1) and an $8 \%(0.33 \mathrm{~kg})$ lower delta of total body mass (follow-up-baseline: $-3.69 \mathrm{~kg}$ for A-allele carriers instead of $-4.02 \mathrm{~kg}$ for noncarriers, $p=.023$ ) following the Sportfasting intervention (Figure 1c).

\section{Discussion}

This study was performed to assess the scientific value of an established protocol termed Sportfasting, involving a 10-day nutritional 
(a)

rs225014 (DIO2)

Total body mass (kg)

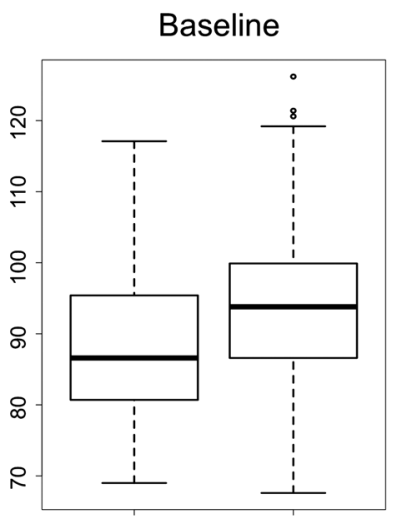

TT $\quad \mathrm{CC}+\mathrm{CT}$

Total lean mass mass $(\mathrm{kg})$
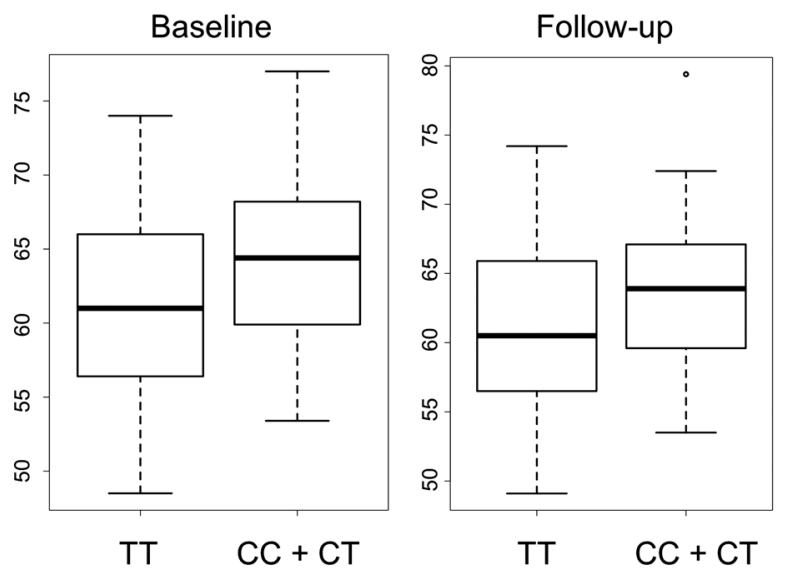

(b) rs1053049 (PPARD)

Total body mass $(\mathbf{k g})$

Baseline

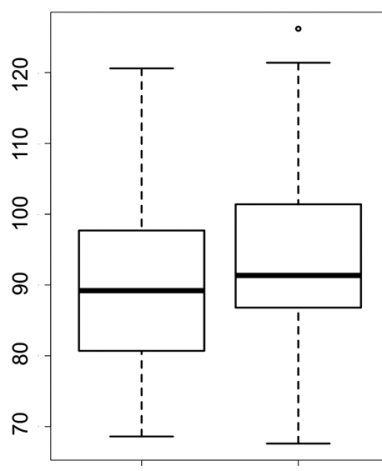

TT

$\mathrm{CC}+\mathrm{CT}$

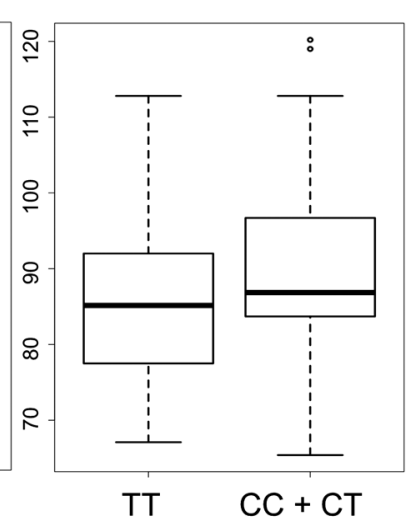

(c)

rs35767 (IGF1)
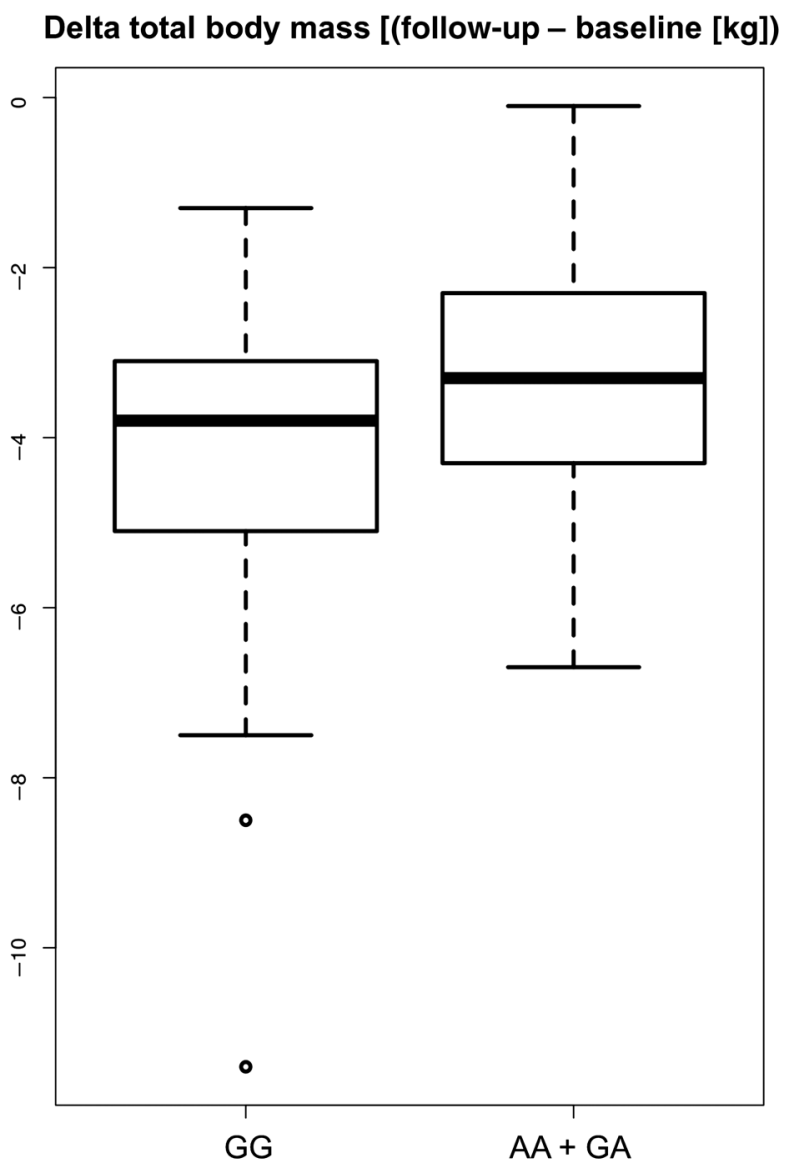

Figure 1 - Associations between SNPs and body mass, lean mass, and BMI. (a) Association between rs225014 (DIO2) and total body mass (kg), total lean mass $(\mathrm{kg})$, and BMI $\left(\mathrm{kg} / \mathrm{m}^{2}\right)$, both at baseline and follow-up; (b) association between rs 1053049 (PPARD) and total body mass (kg), both at baseline and follow-up; and (c) association between rs35767 (IGF1) and delta total body mass (kg). Throughout, the two genotype groups compared the carriers of the minor allele (heterozygotes and homozygotes combined) versus the homozygous noncarriers of the minor allele. BMI $=$ body mass index; SNPs $=$ single-nucleotide polymorphisms.

intervention combined with endurance exercise, which is currently applied nationwide in The Netherlands. In a baselinefollow-up study involving 107 healthy male participants, wholebody DXA was applied to test the effect of the protocol on several parameters related to body composition. The protocol resulted in significant reductions of the mean values of several parameters tested between the baseline and follow-up, namely, total lean mass, total body mass, total fat mass, BMI, percentage of fat mass 
as a percentage of total body mass, and percentage of fat mass over lean mass. Thus, importantly, not only does the Sportfasting protocol induce a substantial loss of total body mass, but it also elicits an effective loss of fat mass. Although the mean loss of total lean mass reached significance, lean mass as a percentage of total body mass was not reduced. The percentage of android and gynoid fat mass over total fat mass, as well as the ratio of android/gynoid fat mass were significantly reduced in response to the intervention.

Long-term reduced caloric intake alone results not only in the loss of fat mass and total mass, but also in a substantial loss in lean mass, as shown in male and female subjects submitted to reduced energy intake (Das et al., 2017). Recently, 4 weeks of energy restriction (25\% energy restriction) combined with resistance exercise in recreationally active males has been shown to lead to a reduction in fat mass with concurrent maintenance of lean mass (Stratton et al., 2020). Our study, leading to a substantial reduction of fat mass with only a small reduction in lean mass thus achieves similar results on a shorter term, despite differences in the nutritional intervention and exercise setting. During DXA measurement, correct positioning of the subjects was double-checked, and errors due to dehydration and incomplete glycogen repletion (Bone et al., 2017) were avoided by measuring body weight and composition within 7-10 days after the intervention. Although short-term repeat DXA scans showed low coefficients of variation and good reproducibility for whole body mass, lean mass, and fat mass (Moreira et al., 2018), small precision errors known to occur in relation to obesity (Knapp et al., 2015) may have been encountered in a percentage $(15 \%)$ of participants with BMIs of over $30 \mathrm{~kg} / \mathrm{m}^{2}$. Nevertheless, the accuracy of the DXA measurement is reflected by the similar association of rs225014 (DIO2) with both total body mass, BMI, and lean mass, the latter value obtained with the DXA approach. Exercise-induced prevention of substantial loss of lean mass by energy restriction may be explained by the fact that the combination of fasting and exercise in humans in the postexercise period has been shown to rapidly (within $4 \mathrm{hr}$ ) modulate the factors involved in the autophagy-muscle repair process, such as eukaryotic elongation factor 2 (activated by fasting during exercise) and Unc-51 like autophagy-activating kinase 1 (ULK1; repressed by fasting during exercise; reviewed in Giacco et al., 2019). The effect of the Sportfasting protocol on functional aspects and turnover of muscle tissue warrants future studies. One additional beneficial outcome revealed by the DXA measurements was the increased loss of android over gynoid fat by this protocol. Excess android fat in males is associated with obesity-related diseases more so than excess gynoid fat (Bi et al., 2018).

We investigated whether candidate gene polymorphisms could be associated with interindividual variations in baseline characteristics and responses to the Sportfasting protocol. We performed an initial explorative screening for known SNPs involved in muscle metabolism and growth, including some being related to the thyroid state, that strongly influences these parameters. The C-allele $(\mathrm{MAF}=38 \%)$ of the thyroid state-related SNP rs225014 (DIO2) is associated with a 5-7\% higher total body mass, total lean mass, and BMI, and the C-allele (MAF $=24 \%$ ) of SNP rs 1053049 (PPARD) is associated with a 5\% higher total body mass, which was not influenced by the Sportfasting intervention. The direction of these genetic effects is as expected, based on the literature (Canani et al., 2005; Thamer et al., 2008). The observed association between the A-allele (MAF $=22 \%$ ) of the rs35767 SNP (IGF1) with an $8 \%$ smaller change in total body mass is in line with the data from the literature (Ben-Zaken et al., 2013). Although the above associations are intriguing, it should be noted that, to establish if the above associations are real, a larger study sample and replication of the genetic analyses in an independent sample are needed.

This study was set up to scientifically evaluate the outcomes of an established protocol combining short periods of severe energy restriction and exercise, termed Sportfasting. Each individual condition, such as the exercise intervention, the short severe energy restriction period, the refeeding period, and the eventual influence on these parameters of the supplied supplements, was not separately studied, which is a weakness of the study. In addition, longer term follow-up studies with larger numbers of participants are warranted.

In conclusion, based on our findings, the Sportfasting protocol, appreciated as an effective weight-loss program by many volunteers within the Dutch population, is capable of achieving considerable body and fat mass loss with a comparatively low loss of lean mass. This might indicate a beneficial change in body composition, but longer term studies would be needed to confirm sustained effects.

\section{Acknowledgments}

Writing of the original draft, G. delli Paoli, D. van de Laarschot; conceptualization, P. de Lange, M.C. Zillikens; data curation, R. Verkaik, P.P. Arp, G. delli Paoli, A. Giacco, R. Senese; formal analysis, G. dei Paoli, D. van de Laarschot, P.P. Arp, P.M. Jhamai, S.M. Pagnotta, L. Broer, A. Giacco, R. Senese; investigation, E.C.H. Friesema, R. Verkaik, A.G. Uitterlinden, M.C. Zillikens, P. de Lange; methodology, P.P. Arp, P.M. Jhamai, S.M. Pagnotta, L. Broer, M.C. Zillikens; supervision, M.C. Zillikens, A.G. Uitterlinden, A. Lanni, P. de Lange; and writing-review and editing, A.G. Uitterlinden, M.C. Zillikens, P. de Lange. R. Verkaik is head of the company European Nutraceutical Services BV and financially contributed to the study. All other authors declare that they have no conflict of interest.

\section{References}

Agha, M., \& Agha, R. (2017). The rising prevalence of obesity: part A: Impact on public health. Journal of Surgical Oncology, 2, e17.

Anton, S.D., Moehl, K., Donahoo, W.T., Marosi, K., Lee, S.A., Mainous, A.G, 3rd, ... Matson, M.P. (2017). Flipping the metabolic switch: Understanding and applying the health benefits of fasting. Obesity, 26(2), 254-268. doi:10.1002/oby.22065.

Ben-Zaken, S., Meckel, Y., Nemet, D., \& Eliakim, A. (2013). Can IGF-I polymorphisms affect power and endurance athletic performance? Growth Hormone IGF Research, 23(5), 175-178. doi:10.1016/j.ghir. 2013.06.005.

Bhutani, S., Klempel, M.C., Kroeger, C.M., Trepanowski, J.F., Varady, K.A. (2013). Alternate day fasting and endurance exercise combine to reduce body weight and favorably alter plasma lipids in obese humans. Obesity, 21(7), 1370-1379. doi:10.1002/oby.20353.

Bi, X., Loo, Y.T., \& Henry, C.J. (2018). Android fat as a determinant of metabolic syndrome: Sex differences. Nutrition, 57, 127-132. PubMed ID: 30172994 doi:10.1016/j.nut.2018.05.016.

Bocco, B.M., Louzada, R.A., Silvestre, D.H., Santos, M.C., Anne-Palmer, E., Rangel, I.F., ... Werneck-de-Castro, J.P. (2016). Thyroid hormone activation by type 2 deiodinase mediates exercise-induced peroxisome proliferator-activated receptor- $\gamma$ coactivator- $1 \alpha$ expression in skeletal muscle. Journal of Physiology, 594(18), 5255-5269. doi:10.1113/JP272440. 
Bone, J.L., Ross, M.L., Tomcik, K.A., Jeacocke, N.A., Hopkins, W.G., Burke, L.M. (2017). Manipulation of muscle creatine and glycogen changes dual X-ray absorptiometry estimates of body composition. Medicine \& Science in Sports \& Exercise, 49(5),1029-1035. PubMed ID: 28410328 doi:10.1249/MSS.0000000000001174.

Canani, L.H., Capp, C., Dora, J.M., Meyer, E.L., Wagner, M.S., Harney, J.W., .. Maia, A.L. (2005). The type 2 deiodinase A/G (Thr92Ala) polymorphism is associated with decreased enzyme velocity and increased insulin resistance in patients with type 2 diabetes mellitus. Journal of Clinical Endocrinological Metabolism, 90(6), 3472-3478. doi:10.1210/jc.2004-1977.

Das, S.K., Roberts, S.B., Bhapkar, M.V., Villareal, D.T., Fontana, L., Martin, C.K., ... CALERIE-2 Study Group. (2017). Bodycomposition changes in the Comprehensive Assessment of Longterm Effects of Reducing Intake of Energy (CALERIE)-2 study: A 2-y randomized controlled trial of calorie restriction in nonobese humans. American Journal of Clinical Nutrition, 105, 913-927.

de Lange, P., Farina, P., Moreno, M., Ragni, M., Lombardi, A., Silvestri, E., ... Goglia, F. (2006). Sequential changes in the signal transduction responses of skeletal muscle following food deprivation. FASEB Journal, 20, 2579-2581.

de Lange, P., Lombardi, A., Silvestri, E., Goglia, F., Lanni, A., \& Moreno, M. (2008). Peroxisome Proliferator-Activated Receptor Delta: a conserved director of lipid homeostasis through regulation of the oxidative capacity of muscle. PPAR Research, 2008, 172676. doi:10.1155/2008/ 172676.

de Lange, P., Moreno, M., Silvestri, E., Lombardi, A., Goglia, F., \& Lanni, A. (2007). Fuel economy in food-deprived skeletal muscle: Signaling pathways and regulatory mechanisms. FASEB Journal, 2, 3431-3441.

Del Coso, J., Hiam, D., Houweling, P., Pérez, L.M., Eynon, N., \& Lucia, A. (2019). More than a "speed gene": ACTN3 R577X genotype, trainability, muscle damage, and risk for injuries. European Journal of Applied Physiology, 119(1), 49-60. doi:10.1007/s00421-0184010-0.

Douyon, L., \& Schteingart, D.E. (2002). Effect of obesity and starvation on thyroid hormone, growth hormone, and cortisol secretion. Endocrinology and Metabolism Clinics of North America, 31(1), 173-189. PubMed ID: 12055988 doi:10.1016/S0889-8529(01)00023-8.

Eynon, N., Meckel, Y., Sagiv, M., Yamin, C., Amir, R., Sagiv, M., ... Oliveira, J. (2010). Do PPARGC1A and PPARalpha polymorphisms influence sprint or endurance phenotypes? Scandinavian Journal of Medicine \& Science in Sports, 20(1), e145-e150. PubMed ID: 19422653 doi:10.1111/j.1600-0838.2009.00930.x.

Giacco, A., delli Paoli, G., Lanni, A., \& de Lange, P. (2019). Exercise and metabolic health. Deutsche Zeitung fur Sportmedizin, 70(4), 91-96. doi:10.5960/dzsm.2019.364.

Giacco, A., delli Paoli, G., Simiele, R., Caterino, M., Ruoppolo, M., Bloch, W., ... de Lange, P. (2020). Exercise with food withdrawal at thermoneutrality impacts fuel use, the microbiome, AMPK phosphorylation, muscle fibers, and thyroid hormone levels in rats. Physiological Reports, 8(3), e14354. PubMed ID: 32034884 doi:10.14814/phy2.14354.

Hagberg, J.M., Ferrell, R.E., Katzel, L.I., Dengel, D.R., Sorkin, J.D., \& Goldberg, A.P. (1999). Apolipoprotein E genotype and exercise training-induced increases in plasma high-density lipoprotein (HDL)and HDL2-cholesterol levels in overweight men. Metabolism, 48(8), 943-945. doi:10.1016/S0026-0495(99)90185-3.

Jaspers, R.T., Zillikens, M.C., Friesema, E.C., delli Paoli, G., Bloch, W., Uitterlinden, A.G., ... de Lange, P. (2017). Exercise, fasting, and mimetics: Toward beneficial combinations? FASEB Journal, 31(1), 14-28. PubMed ID: 27729415 doi:10.1096/fj.201600652r.
Jenkins, N.D.M., Colquhoun, R.J., Tomko, P.J., Gradnigo, T., Magrini, M.A., Muddle, T.W.D., . . El-Sohemy, A. (2018). Genetic variant in the 2-adrenergic receptor (Arg16Gly) influences fat-free mass, muscle strength and motor unit behaviour in young men. Experimental Physioliology, 103(12), 1645-1655. doi:10.1113/EP087145.

Knapp, K.M., Welsman, J.R., Hopkins, S.J., Shallcross, A., Fogelman, I., \& Blake, G.M. (2015). Obesity increases precision errors in total body dual-energy x-ray absorptiometry measurements. Journal of Clinical Densitometry, 18(2), 209-216. PubMed ID: 25087044 doi:10.1016/j.jocd.2014.06.001.

McAtee, B.I., \& Jager, J.D. (2010). Manganese superoxide dismutase: Effect of the ala16val polymorphism on protein, activity, and mRNA levels in human breast cancer cell lines and stably transfected mouse embryonic fibroblasts. Molecular and Cellular Biochemistry, 335(1-2), 107-118. PubMed ID: 19756960 doi:10.1007/s11010-009-0247-6.

Moreira, O.C., Oliveira, C.E.P., \& De Paz, J.A. (2018). Dual energy X-ray absorptiometry (DXA) reliability and intraobserver reproducibility for segmental body composition measuring. Nutrición Hospitalaria, 17, 35, 340-345.

Muñoz, V.R., Vieira, R.F.L., \& Gaspar, R.C. (2020). When fasting results in metabolic damage: A matter of gender. The Journal of Physiology. Advance online publication. doi:10.1113/jp279873

Notay, K., Klingel, S.L., Lee, J.B., Doherty, C.J., Seed, J.D., Swiatczak, M., ... Millar, P J. (2018). TRPV1 and BDKRB2 receptor polymorphisms can influence the exercise pressor reflex. Journal of Physiology, 596(21), 5135-5148. PubMed ID: 30206938 doi:10.1113/JP276526.

Ohkubo, Y., Sekido, T., Nishio, S.I., Sekido, K., Kitahara, J., Suzuki, S., \& Komatsu, M. (2019). Loss of $\mu$-crystallin causes PPAR $\gamma$ activation and obesity in high-fat diet-fed mice. Biochemical and Biophysical Research Communications, 508(3), 914-920. PubMed ID: 30545633 doi:10.1016/j.bbrc.2018.12.038.

Petr, M., Stastny, P., Zajac, A., Tufano, J.J., \& Maciejewska-Skrendo, A. (2018). The role of peroxisome proliferator-activated receptors and their transcriptional coactivators gene variations in human trainability: A systematic review. International Journal of Molecular Sciences, 19(5), 1472. PubMed ID: 29762540 doi:10.3390/ijms 19051472.

Povel, C.M., Feskens, E.J., Imholz, S., Blaak, E.E., Boer, J.M., \& Dollé, M.E. (2010). Glucose levels and genetic variants across transcriptional pathways: Interaction effects with BMI. International Journal of Obesity, 34(5), 840-845. doi:10.1038/ijo.2009.302.

$\mathrm{R}$ Core Team. (2017). $R$ : A language and environment for statistical computing. Vienna, Austria: R Foundation for Statistical Computing. Retrieved from https://www.R-project.org/

Ronca, F., \& Raggi, A. (2018). Role of the HPRG component of striated muscle AMP deaminase in the stability and cellular behaviour of the enzyme. Biomolecules, 8(3), 79. doi:10.3390/biom8030079.

Samuels, M.H., Kolobova, I., Antosik, M., Niederhausen, M., Purnell, J.Q., \& Schuff, K.G. (2017). Thyroid function variation in the normal range, energy expenditure, and body composition in L-T4-treated subjects. Journal of Clinical and Endocrinological Metabolism, 102(7), 2533-2542. doi:10.1210/jc.2017-00224.

Senese, R., Lasala, P., Leanza, C., \& de Lange, P. (2014). New avenues for regulation of lipid metabolism by thyroid hormones and analogs. Frontiers in Physiology, 5, 475. PubMed ID: 25538628 doi:10.3389/ fphys.2014.00475.

Stratton M.T., Tinsley G.M., Alesi, M.G., Hester, G.M., Olmos, A.A., Serafini, P.R., ... VanDusseldorp, T.A. (2020). Four weeks of timerestricted feeding combined with resistance training does not differentially influence measures of body composition, muscle performance, resting energy expenditure, and blood biomarkers. Nutrients, 12(4), 1126. PubMed ID: 32316561 doi:10.3390/nu12041126. 
Thamer, C., Machann, J., Stefan, N., Schäfer, S.A., Machicao, F., Staiger, H., ... Haring, H.U. (2008). Variations in PPARD determine the change in body composition during lifestyle intervention: a whole-body magnetic resonance study. Journal of Clinical and Endocrinological Metabolism, 93(4), 1497-1500 doi:10.1210/jc. 2007-1209.

Thompson, P.D., Tsongalis, G.J., Seip, R.L., Bilbie, C., Miles, M., Zoeller, R., .. Moyna, N. (2004). Apolipoprotein E genotype and changes in serum lipids and maximal oxygen uptake with exercise training. Metabolism, 53(2), 193-202. PubMed ID: 14767871 doi:10.1016/ j.metabol.2003.09.010.

Tsianos, G.I., Evangelou, E., Boot, A., Zillikens, M.C., van Meurs, J.B., Uitterlinden, A.G., \& Ioannidis, J.P. (2010). Associations of polymorphisms of eight muscle- or metabolism-related genes with performance in Mount Olympus marathon runners. Journal of Applied Physiology, 108(3), 567-574. doi:10.1152/japplphysiol. 00780.2009.

Valdivieso, P., Vaughan, D., Laczko E., Brogioli M., Waldron S., Rittweger J., \& Flück, M. (2017). The metabolic response of skeletal muscle to endurance exercise is modified by the ACE-I/D gene polymorphism and training state. Frontiers in Physiol, 8, 993. doi:10.3389/fphys.2017.00993.
Van Proeyen, K., Szlufcik, K., Nielens, H., Ramaekers, M., \& Hespel, P. (2011). Beneficial metabolic adaptations due to endurance exercise training in the fasted state. Journal of Applied Physiology, 110(1), 236-245. doi:10.1152/japplphysiol.00907.2010.

Vasiliadis, I., Kolovou, G., Kolovou, V., Giannakopoulou, V., Boutsikou, M., Katsiki, N., ... Cokkinos, D.V. (2014). Gene polymorphisms and thyroid function in patients with heart failure. Endocrine, 45(1), 46-54. PubMed ID: 23543433 doi:10.1007/ s12020-013-9926-x.

Verkaik, R. (2015). The sportfasting principle. Rotterdam, The Netherlands: European Health \& Fitness Group BV.

Walter, S., Mackenbach, J., Vokó, Z., Lhachimi, S., Ikram, M.A., Uitterlinden, A.G., ... Tiemeier, H. (2012). Genetic, physiological, and lifestyle predictors of mortality in the general population. American Journal of Public Health, 102(4), e3-e10. PubMed ID: 22397355 doi:10.2105/AJPH.2011.300596.

Wijngaarden, M.A., Bakker, L.E., van der Zon, G.C., 't Hoen, P.A., van Dijk, K.W., Jazet, I.M., . . . Guigas, B. (2014). Regulation of skeletal muscle energy/nutrient-sensing pathways during metabolic adaptation to fasting in healthy humans. American Journal of Physiology Endocrinology and Metabolism, 307(10), E885-E895. PubMed ID: 25249505 doi:10.1152/ajpendo.00215.2014. 


\section{Addendum: Intake Questionnaire and Exclusion Criteria}

1. Are you able to run or cycle for $30 \mathrm{~min}$ for 10 days consecutively?

2. Do you have a medical condition, or do you use any prescribed medication?
3. Have you suffered or are you suffering anorexia or associated illnesses?

4. Are you motivated and willing to conform to the exercise and nutritional guidelines? 


\section{Erratum: delli Paoli et al. (2020)}

In the original publication of this article, the copyright was assigned to Human Kinetics, Inc. The authors subsequently obtained Open Access distributed under the terms of the Creative Commons Attribution License CC BY 4.0, which reverted copyright back to the authors. This online version of this article has been corrected. 